\title{
普通鋼精鍊プロセスから排出された電気炉酸化スラグ の淡水への繰返し溶出試験
}

横山 誠二*・鈴木 玲人*2・ニク ヒシャムディン ビンムハンマド ノル*3 兼松 秀行 $* 4 \cdot$ 小川 亜希子 $* 5$. 高橋 利幸 $* 6$. 伊崎 昌伸 $*$ - 梅本 実*

Serial Batch Elution of Electric Arc Furnace Oxidizing Slag Discharged from Normal

Steelmaking Process into Fresh Water

Seiji Yokoyama, Akito Suzuki, Nik Hisyamudin Bin Muhd Nor, Hideyuki Kanematsu, Akiko Ogawa, Toshiyuki TAKAHASHI, Masanobu IZAKI and Minoru UMEMOTO

Synopsis : The serial batch leaching test of an electronic arc furnace oxidizing slag was performed on the basis of JIS K 0058-1 to investigate the safety of the slag and to clarify the elution mechanism. The slag which was discharged at the time of refining of normal steel was used for this experiment. The slag was dissolved in water whose initial $\mathrm{pH}$ was 6.0. After that, the slag was naturally dried. This operation was performed 12 times successively.

The dissolution behaviors of $\mathrm{Ca}$ and $\mathrm{Mg}$ were expressed by the parabolic law. That of $\mathrm{Si}$ was expressed by the linear law. The dissolutions of them from the slag were controlled by the diffusion through pore and the surface layer through the surface layer where compositions of $\mathrm{FeO}$ and $\mathrm{Al}_{2} \mathrm{O}_{3}$ were high. Generally, the dissolve concentrations decreased with the increase in the number of the elution times. The environmentally regulated substances were not detected or less than the levels of the environmental quality standards for soil. $\mathrm{Ba}, \mathrm{Mn}, \mathrm{Mo}, \mathrm{K}, \mathrm{Na}, \mathrm{Sr}$ and $\mathrm{W}$ were detected as minor element except for the environmentally regulated elements. Generally, the detected environmentally regulated substances and the other minor elements decreased with the number of the elution times. During the elution of the slag, the $\mathrm{pH}$ of the aqueous solution steeply increased initially, and it decreased afterwards. The $\mathrm{pH}$ decreased with the increase in the number of the elution times.

Key words : elution; oxidizing slag; environmentally quality standards; $\mathrm{pH}$.

\section{1. 緒言}

鉄鋼業ではスラグが恒常的に排出されている。日本では， スラグは年間約 35.6 百万トン生産され，そのうち約 $8.5 \%$ が電気炉スラグである。スラグはこれまでセメント原料, 路盤材やコンクリート骨材などに使用されてきた。しかし， 公共事業の削減に伴いこれらの需要が減少し, 工場敷地内 に野積みされている。そのためスラグの新たな用途開発が 進められており，海域での使用が検討されている。

鉄鋼スラグは植物に必須な元素を多く含んでいる。その ため，スラグは土㥽改良材や肥料として使用されてきた。 スラグを海域で使用した場合，スラグからの鉄とシリコン の溶出は植物プランクトンの増加につながる。シリコンは 珪藻の款の形成に必要な元素である。海洋には硝酸, リン 酸, ケイ酸濃度が高いにもかかわらず植物プランクトンの
少ない, 高栄養素低生産海域(HNLC)が存在する ${ }^{2)}$ 。水域 では鉄イオンの不足が植物プランクトンの増殖を抑制す る。スラグの溶解による水域へのシリコンや鉄イオン濃度 の増加は植物プランクトンの増殖につながり, それが海域 への二酸化炭素吸収量を増加させると考えられる。しかし ながら，スラグは環境基準によって規制された重金属を含 む。そのため，スラグの溶出には多くの研究がある ${ }^{3-8)}$ 。

前報では, スラグからの環境規制された重金属の溶出濃 度と溶出機構を明らかにするために, スラグの溶出挙動に およぼす初期 $\mathrm{pH}$ とスラグの初期粒度の影響について調查 した ${ }^{9,10)}$ 。スラグは実使用前に含有量試験や溶出試験に よって安全を確認しなければならない11,12)。しかし, これ らの試験に適合しても，スラグを実使用した場合に溶出濃 度が環境基準を超える場合がごく稀にある。本研究では， スラグの水への溶出に関する基礎研究の一環として, スラ

原著論文：ISIJ Int., Vol. 50 (2010), No. 4, pp. 630-638

平成 22 年 6 月 21 日受付 平成 22 年 9 月 6 日受理 (Received June 21, 2010; Accepted Sep. 6, 2010; originally published in ISIJ Int., Vol. 50, 2010, No. 4, pp. 630-638) * 豊橋技術科学大学機械工学系 (Department of Mechanical Engineering, Toyohashi University of Technology, 1-1 Hibarigaoka Tempaku-cho Toyohashi Aichi 441-8580) * 2 豊橋技術科学大学大学院 (現：(株) 神戸製鋼所) (Graduate school of Toyohashi University of Technology, now Kobe Steel, Ltd.)

*3 トゥン フセイン オン マレーシア大学 機械生産工学科（現：豊橋技術科学大学大学院) (Department of Mechanical and Manufacturing Engineering, University Tun Hussein Onn Malaysia, now Graduate School of Toyohashi University of Technology)

* 4 鈴鹿工業高等専門学校材料工学科 (Department of Materials Science and Technology, Suzuka National College of Technology)

* 5 鈴鹿工業高等専門学校生物応用化学科 (Department of Chemistry and Biochemistry, Suzuka National College of Technology)

* 6 都城工業高等専門学校物質工学科 (Department of Chemical Science and Technology, Miyakonojo National College of Technology) 
グの安全性の確認と溶出機構の調査を目的として, スラグ の連続回分溶出試験を行った。

\section{2. 実験方法}

\section{$2 \cdot 1$ スラグ}

実験には電気炉普通鋼溶製時に排出された酸化スラグを 使用した。スラグは粉砕後，粒径 $1 \sim 2 \mathrm{~mm}$ にふるい分けら れたものを溶出試験に使用した。Table 1にスラグの化学組 成を示す。組成はスラグをアルカリ融解後, ICPで分析し， 得られた金属成分を表に示す酸化物に換算した。スラグ表 面の組成はEPMA で求め, 同様に酸化物に換算して表に示 した。両組成はほぼ等しかった。Fig. 1に，スラグのXRD 分析の結果を示す。スラグは $\mathrm{FeO}, 2 \mathrm{CaO} \cdot \mathrm{SiO}_{2}, \mathrm{MgFe} \mathrm{AlO}_{4}$ および $\mathrm{FeO} \cdot \mathrm{Al}_{2} \mathrm{O}_{3}$ より構成されていた ${ }^{10)}$ 。

\section{$2 \cdot 2$ 実験方法}

実験装置と方法は前報 ${ }^{10)} て ゙$ 詳述したので，ここでは略記 する。溶出試験はJIS K 0058-1（スラグ類の化学物質試験 方法一第 1 部：溶出量試験方法「利用有姿による試験」）に もとづいて行った。Fig. 2 に装置の概略図を示す。装置の 中で水と接触する部分はすべて PTFE製である。装置は, 塵などの混入を防ぐため, ビニールシート製の簡易グロー
ブボックス内に置かれている。スラグ $100 \mathrm{~g}$ を容器に入れ たのち, 純水と超精密分析用塩酸で $\mathrm{pH}=6.0$ になるように あらかじめ調製された水溶液を容器に静かに注いだ。その 後, 容器内の水溶液を $100 \mathrm{rpm}$ の回転速度で擋拌した。ス ラグは擋挥中静置していた。水溶液はホールピペットで採 取した後，孔径 $0.45 \mu \mathrm{m}$ のフィルターを通して分析に供し た。

スラグの主要元素である $\mathrm{Al}, \mathrm{Ca}, \mathrm{Fe}, \mathrm{Mg}$ および $\mathrm{Si}$ の溶出 濃度測定については溶出試験を $48 \mathrm{~h}$ 行った。その後，スラ グは前述したフィルターを通して分離した。分離されたス ラグは濾紙上で約 $48 \mathrm{~h}$ 自然乾燥した。スラグに水の付着が ないことを確認した後, 上述した方法で再び溶出試験に供 した。シリアルバッチテスト中は同一のスラグを使用した。 溶出 $1,2,3,5,7,12$ 回目のろ液についてはICPで分析した。 水素イオン濃度指数 $(\mathrm{pH})$ を $\mathrm{pH}$ メーターで測定した。

環境規制元素などのほかの微量元素についてはJISにも とづいてスラグの溶出試験は $6 \mathrm{~h}$ 行った。その後スラグは フィルターを通して分離され，それを $48 \mathrm{~h}$ 自然乾燥した。 この微量元素についての溶出試験は溶出 $1,2,4,9$ 回目につ いて行った。そのほかの溶出回数の溶出試験は主要元素に ついてのそれと同様に行った。このシリアルバッチ溶出試 験は同一のスラグについて行ったが, 主要元素の溶出に用

Table 1. Chemical compositions of slag before elution test and after 12 times of elution test, and pulverized slag particle after elution test (Average and confidence limit of 95\%)

\begin{tabular}{|c|c|c|c|c|c|c|c|c|c|c|c|}
\hline & $\begin{array}{l}\text { Particle } \\
\text { size, d / } \\
\text { mm }\end{array}$ & $\mathrm{FeO}$ & $\mathrm{SiO}_{2}$ & $\mathrm{CaO}$ & $\mathrm{Al}_{2} \mathrm{O}_{3}$ & $\mathrm{MgO}$ & $\mathrm{MnO}$ & $\mathrm{Cr}_{2} \mathrm{O}_{3}$ & $\mathrm{ZnO}$ & $\mathrm{NiO}$ & $\mathrm{CuO}$ \\
\hline $\begin{array}{l}\text { Slag before } \\
\text { experiment* }\end{array}$ & $1-2$ & $\begin{array}{l}35.1 \\
\pm 3.2\end{array}$ & $\begin{array}{l}19.2 \\
\pm 2.5\end{array}$ & $\begin{array}{l}20.8 \pm \\
2.3\end{array}$ & $\begin{array}{l}15.2 \pm \\
2.0\end{array}$ & $\begin{array}{l}4.1 \pm \\
1.2\end{array}$ & $\begin{array}{l}5.1 \\
\pm 1.1\end{array}$ & $\begin{array}{l}0.43 \pm \\
0.12\end{array}$ & $\begin{array}{l}0.071 \\
\pm \\
0.023\end{array}$ & $\begin{array}{l}0.028 \\
\pm \\
0.012\end{array}$ & $\begin{array}{l}0.025 \\
\pm \\
0.011\end{array}$ \\
\hline $\begin{array}{l}\text { Slag before } \\
\text { experiment** }\end{array}$ & $1-2$ & $\begin{array}{l}36.0 \\
\pm 2.9\end{array}$ & $\begin{array}{l}17.9 \\
\pm 1.2\end{array}$ & $\begin{array}{l}20.8 \\
\pm 1.6\end{array}$ & $\begin{array}{r}15.7 \\
\pm 1.5\end{array}$ & $\begin{array}{l}3.2 \\
\pm 0.7\end{array}$ & $\begin{array}{l}6.2 \\
\pm 0.5\end{array}$ & $\begin{array}{l}0.4 \\
\pm 0.2\end{array}$ & & & \\
\hline $\begin{array}{l}\text { Slag after } 12 \\
\text { times of } \\
\text { elution test** }\end{array}$ & $0.6-2$ & $\begin{array}{l}38.3 \\
\pm 2.9\end{array}$ & $\begin{array}{l}19.5 \\
\pm 1.5\end{array}$ & $\begin{array}{l}12.9 \\
\pm 1.2\end{array}$ & $\begin{array}{l}19.5 \\
\pm 1.4\end{array}$ & $\begin{array}{l}4.0 \\
\pm 0.5\end{array}$ & $\begin{array}{l}5.5 \\
\pm 0.5\end{array}$ & $\begin{array}{l}0.3 \\
\pm 0.1\end{array}$ & & & \\
\hline $\begin{array}{l}\text { Pulverized } \\
\text { slag particle } \\
\text { after elution } \\
\text { test*** }\end{array}$ & $<0.1$ & $\begin{array}{l}26.3 \\
\pm 3.0\end{array}$ & $\begin{array}{l}24.8 \\
\pm 1.6\end{array}$ & $\begin{array}{l}17.6 \\
\pm 1.3\end{array}$ & $\begin{array}{l}21.2 \\
\pm 1.5\end{array}$ & $\begin{array}{c}5.6 \\
\pm 0.4\end{array}$ & $\begin{array}{c}4.2 \\
\pm 0.4\end{array}$ & $\begin{array}{c}0.3 \\
\pm 0.2\end{array}$ & & & \\
\hline
\end{tabular}

*: ICP, **EPMA

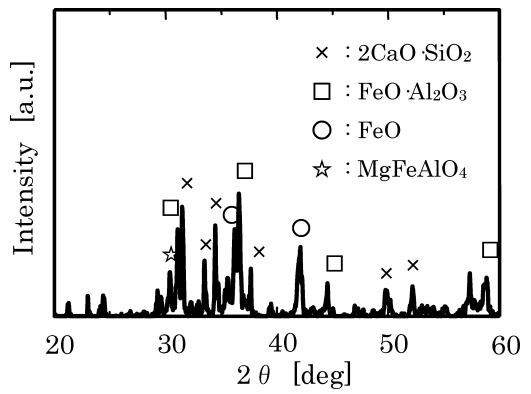

Fig. 1. XRD pattern of electric arc furnace oxidizing slag. ${ }^{10)}$

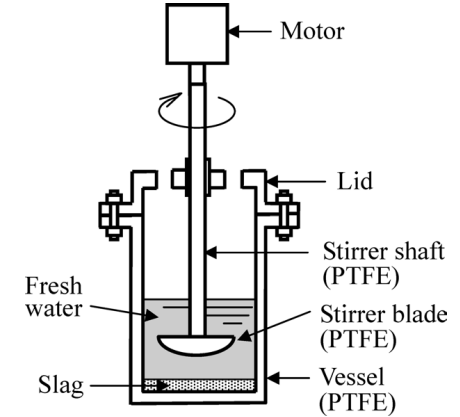

Fig. 2. Schematic diagram of experimental apparatus. 
いたそれとは異なっている。環境規制物質および微量元素 の分析は外部機関に委託した。

\section{3. 結果および考察}

\section{$3 \cdot 1 \mathrm{pH}$ 変化}

溶出試験中の $\mathrm{pH}$ の経時変化を Fig. 3 に例示する。全般的 に見て, 溶出試験開始後 $\mathrm{pH}$ は急激に増大した後, 時間と ともに徐々に減少した。これより，スラグには緩衝作用が あるようである ${ }^{10)}$ 。Fig. 4 に溶出回数による $\mathrm{pH}$ の変化を示 す。 $\mathrm{pH}$ は溶出回数の増加とともに減少した。

生活環境の保全に関する環境基準の $\mathrm{pH}$ の許容範囲を Fig. 3 に, Fig. 4 にとの上限值を示した。この許容範囲は， 工業用水 2 級, 3 級, および環境保全を除いた河川, 湖沼 に適用される。全般的に見て, $\mathrm{pH}$ は溶出初期に環境基準 の上限を超えた。水質污濁防止法には溶出試験も含有量試 験もなく，水質を監視する法律である。したがって，本条 件での $\mathrm{pH}$ が環境基準を超えていても法律に抵触するわけ ではない。しかし，スラグを水域で使用する場合には， $\mathrm{pH}$ に注意しなければならない。また，これらの結果は， 本シリアルバッチ試験のようにスラグを水洗いすれば $\mathrm{pH}$ の増加を防げることを示している。

\section{$3 \cdot 2$ 主要元素の溶出}

\section{$3 \cdot 2 \cdot 1$ 溶出挙動}

Fig. 5 Fig. 7 にスラグから水への $\mathrm{Ca}, \mathrm{Si}$ および $\mathrm{Mg}$ の溶出 挙動を示した。全般的に見て, それらの溶出濃度は溶出試 験開始直後に急激に増大した後, 緩やかに増加した。

Fig. 5 に示したように, 溶出 2 回目の最終の Ca濃度は溶

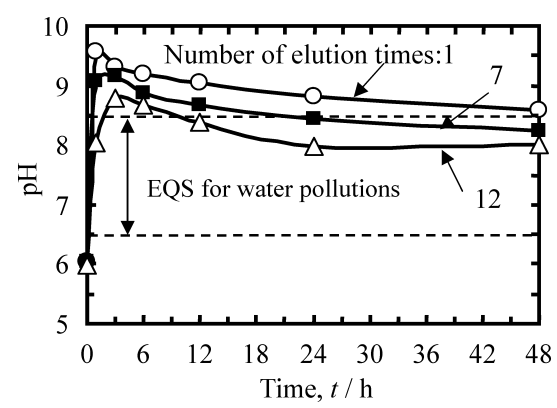

Fig. 3. Example of change in $\mathrm{pH}$ with time. EQS is the environmental quality standards.

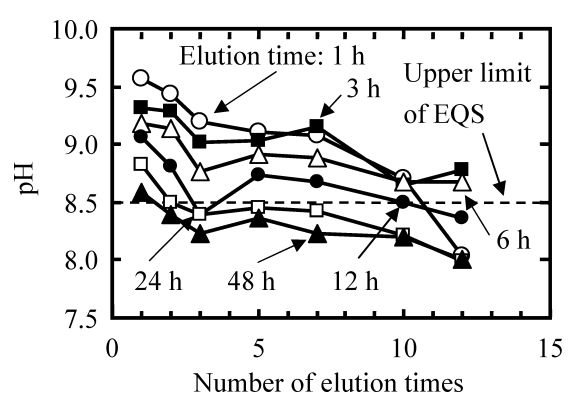

Fig. 4. Change in $\mathrm{pH}$ with number of elution times.
出 1 回目のそれよりも小さい。溶出 3 回目の最終の $\mathrm{Ca}$ 濃度 は溶出 2 回目のそれよりも大きい。溶出 5 回目の最終の Ca 濃度は溶出 3 回目のそれよりも小さく，その濃度は溶出 2 , 7, 10 回目のそれとほぼ同じであった。溶出 12 回目の Caの 溶出最終濃度は10回目のそれとよりも小さかった。Fig. 6 に示したように, 溶出 2 回目の $\mathrm{Si}$ の溶出最終濃度は溶出 1 回目のそれよりも小さかったが, 溶出 $2,3,5$ 回目のそれは ほほ同じであった。溶出 7 回目の $\mathrm{Si}$ の最終溶出濃度は溶出 5 回目のそれよりも大きく，これ以降溶出回数の増加とと もに $\mathrm{Si}$ の最終溶出濃度は減少した。溶出回数の $\mathrm{Ca}$ と $\mathrm{Si}$ の 溶出濃度におよぼす影響は明確ではないが, 全体的な傾向 として, それらの濃度は溶出回数の増加とともに減少して いる。 $\mathrm{Mg}$ の溶出濃度は, Fig. 7 に示すように, 溶出回数と ともに減少した。ここで, 溶出 12 回目の $\mathrm{Ca}$ の溶出濃度は 溶出試験初期に時間遅れが見られる。

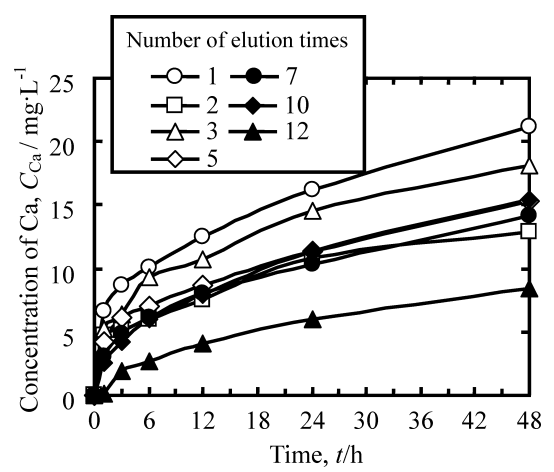

Fig. 5. Change in concentration of $\mathrm{Ca}$ with time.

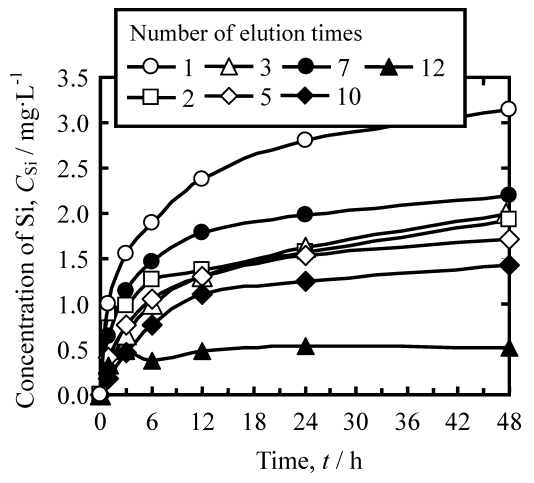

Fig. 6. Change in concentration of Si with time.

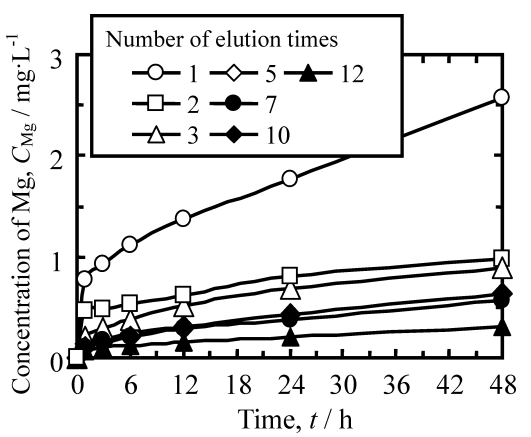

Fig. 7. Change in concentration of $\mathrm{Mg}$ with time. 
Fig. 8 にスラグから水への $\mathrm{Al}$ の溶出挙動を示す。全般的 に見て, 溶出 $\mathrm{Al}$ 濃度の経時変化は上に凸な曲線で表され る。前報 ${ }^{10)}$ で述べたように, $\mathrm{Al}_{2} \mathrm{O}_{3}$ の溶解は,

$\mathrm{Al}_{2} \mathrm{O}_{3(\mathrm{~s})}+\mathrm{H}_{2} \mathrm{O}=2 \mathrm{AlO}_{2}^{-}+2 \mathrm{H}^{+}$

で表される。ここで，下付きのs は固体を表す。Fig. 3 に 示したように, $\mathrm{pH}$ は溶出初期に増加した後, 溶出の進行 に伴い減少する。したがって, 溶出初期に溶出した Alイ オンは, pHの減少に伴い,

$\mathrm{AlO}_{2}^{-}+\mathrm{H}_{2} \mathrm{O}+2 \mathrm{H}^{+}=\mathrm{Al}(\mathrm{OH})_{3(\mathrm{~s})}$

式(2)の反応が進行して減少する。したがって, 溶出 $\mathrm{Al}$ の溶出挙動は極大值をもつ曲線で表される。溶出回数と溶 出 $\mathrm{Al}$ 濃度には明瞭な関係はなかった。

Fig. 9 にFeの溶出挙動を示す。ここで, 溶出 7 回目と 12 回目の Feの溶出濃度はICPの分析下限であった。全般的に 見て, $\mathrm{Fe}$ の溶出濃度の経時変化は, 溶出 5 回目のそれを除 いて，2つの極大をもつ曲線で表される。 $\mathrm{Fe} の$ 溶出挙動は

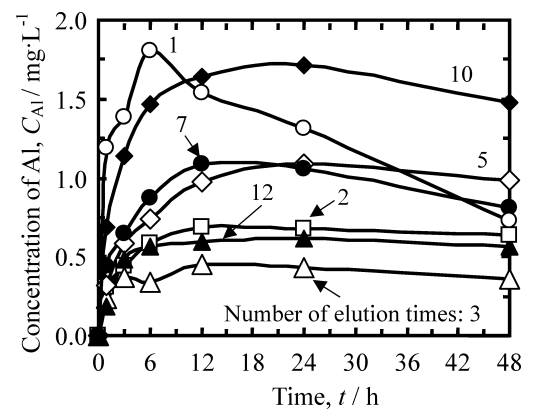

Fig. 8. Change in concentration of $\mathrm{Al}$ with time.

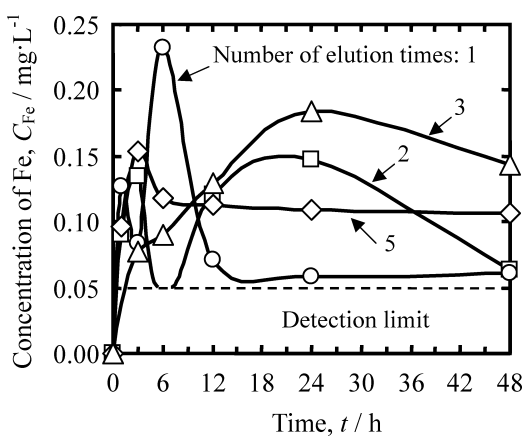

Fig. 9. Change in concentration of $\mathrm{Fe}$ with time.
明らかではないが, $\mathrm{FeO}$ の溶解, 溶出した $\mathrm{Fe}^{2+}$ の酸化, $\mathrm{Fe}(\mathrm{OH})_{3}$ の生成と溶解がその溶出挙動に関与していると思 われる ${ }^{10)}$ 。

ここで, $\mathrm{Al}, \mathrm{Ca}, \mathrm{Fe}, \mathrm{Mg}$ および $\mathrm{Si}$ の溶出濃度を比較する と, $\mathrm{Ca}$ の溶出濃度が最も高く, $\mathrm{Si}$ と $\mathrm{Mg}$ のそれはほぼ同等 で, $\mathrm{Ca}$ に次いで高い。次に, $\mathrm{Al}, \mathrm{Fe}$ の濃度の順に小さくな る。

\section{$3 \cdot 2 \cdot 2$ スラグの観察}

前述したように，スラグの初期の大きさは $1 \sim 2 \mathrm{~mm}$ であ る。溶出試験前のスラグ断面と元素の分布を Fig.10に示す。 $\mathrm{Al}, \mathrm{Ca}, \mathrm{Fe}, \mathrm{Mg}$ と $\mathrm{Si}$ はスラグ全体に存在しているが，それ の濃度の高い相が局在している。溶出 12 回後のスラグ粒 子と元素の分布を Fig.11に示す。溶出 12 回後のスラグ粒 子は, Table 1に示したように, 0.6〜2 mmの大きさであっ た。 $\mathrm{Al}$ と $\mathrm{Fe}$ の濃度の高い相がスラグ粒子表面に部分的に 存在している。 $\mathrm{Al}$ と $\mathrm{Fe}$ は水にほとんど溶解しないので, それらは溶けずにスラグ表面に残っている。Si はスラグ 全体に分布しているが，その濃度の高い部分はスラグ表面 ではなく内部に位置している。Ca濃度の高い相は Si濃度 の高い相よりもより粒子内部に存在している。 $\mathrm{Mg}$ 濃度の 高い相はスラグ表面に存在していない。ここで, 気孔の大 きさとその長さはスラグの溶出により大きくなると思われ るが, Fig.10 と Fig.11に示した粒子の比較からはそれは判

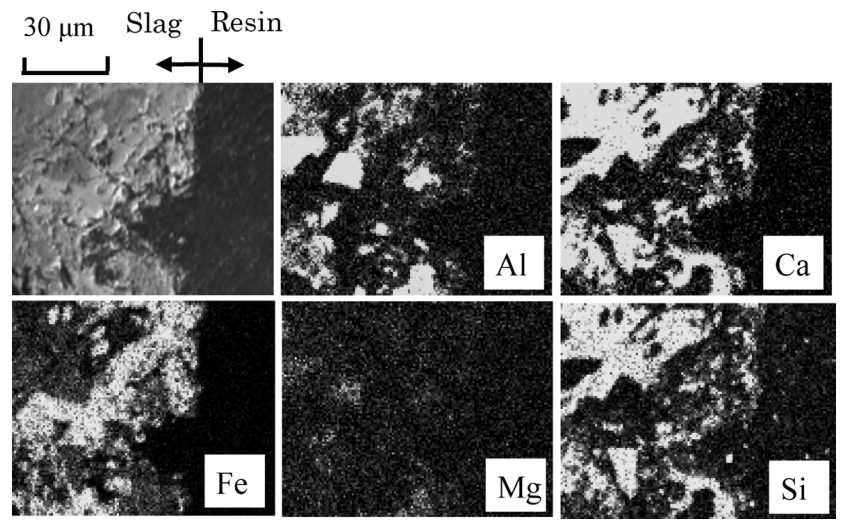

Fig. 10. SEM image of cross section of initial slag and distributions of main elements.
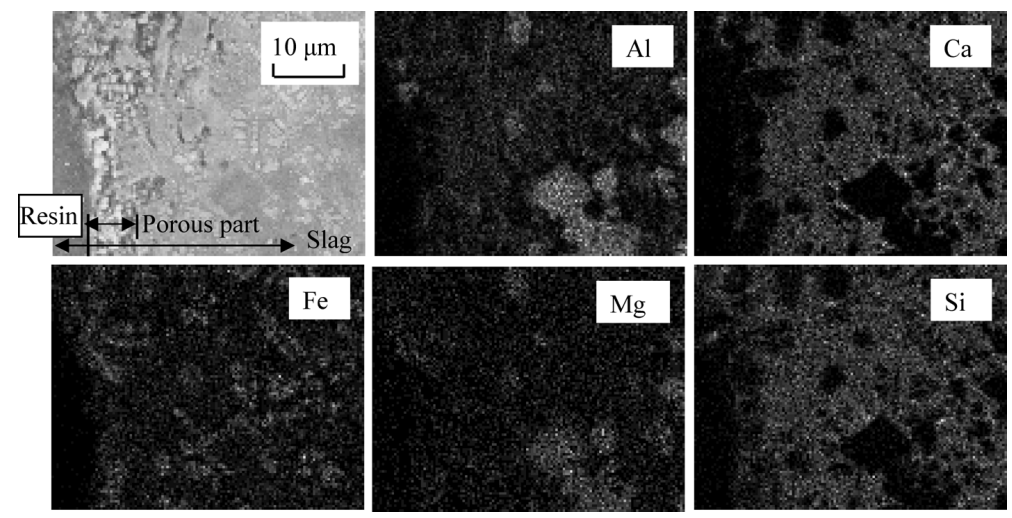

Fig. 11. SEM image of cross section of porous surface of slag and distributions of main elements of slag after 12 times of elution test. 

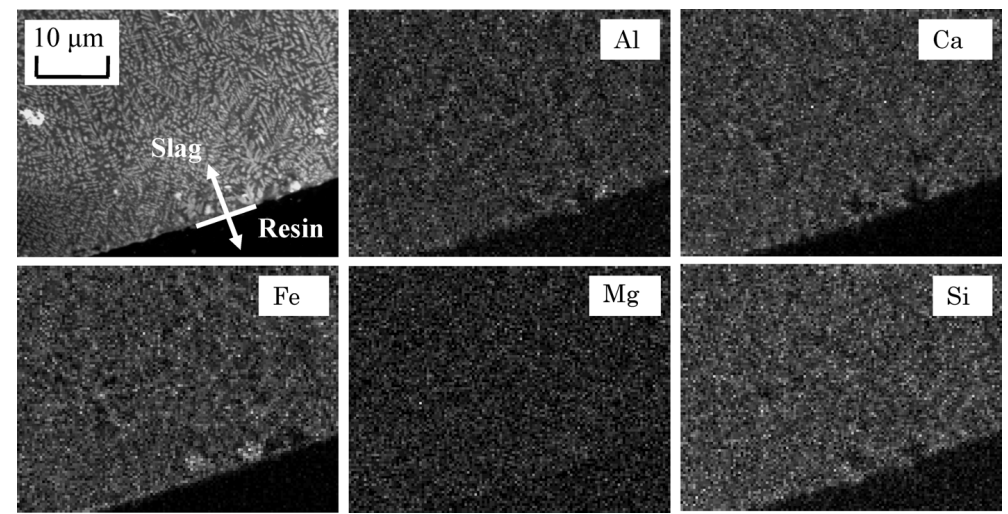

Fig. 12. SEM image of cross section of smooth surface of slag and distributions of main elements of slag after 12 times of elution test.

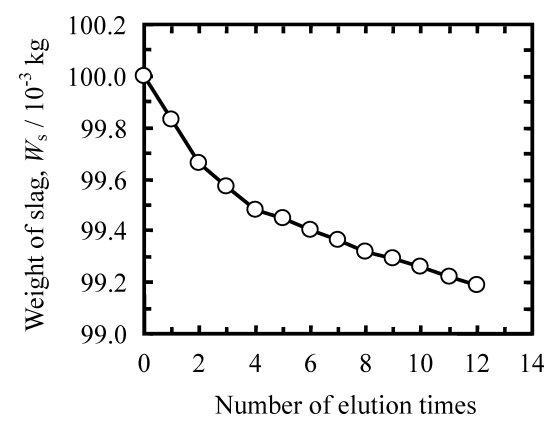

Fig. 13. Change in weight of slag with number of elution times.

断できない。

Fig.12に示したように，Fig.11とは異なる滑らかなスラ グ表面がある。スラグの溶出の有無にかかわらず，スラグ の表面は全体あるいは部分的に滑らかである。滑らかな表 面をもつスラグには $\mathrm{FeO}$ 濃度の高い多数のデンドライトが 均質に分散しているという特徵がある。巨視的に見れば, $\mathrm{Al}, \mathrm{Ca}, \mathrm{Fe}, \mathrm{Mg}$ と $\mathrm{Si}$ は均質に分布しているが，スラグ外周 部に沿って Feが存在している。デンドライト近傍のスラ グ相は溶出するので, スラグの断面観察では Feがスラグ 表面を覆っているかのように見える。

$\mathrm{Al}, \mathrm{Ca}, \mathrm{Fe}, \mathrm{Mg}$ 打よび $\mathrm{Si}$ の濃度分布を求めるために EPMAの線分析も行ったが, 使用したEPMAの分析精度内 で有意な分布は求められなかった。そこで, 溶出を 12 回 行った後のスラグ表面の化学組成を求めた。Table 1 にその 組成を初期の組成とともに示した。 $\mathrm{Al}_{2} \mathrm{O}_{3}$ と $\mathrm{FeO}$ の組成は 実験前の組成よりも大きい。線分析で濃度分布が求まらな かったので, これらの成分で構成された層は薄いと考えら れる。溶出 12 回後のスラグのXRD パターンは Fig. 1に示 した溶出前のそれとほぼ同じであった。熱力学的に見て生 成が予想される水酸化物や炭酸塩などはXRDでは同定で きなかった。しかしながら, 12 回溶出した後の数個のス ラグは赤褐色をしており, $\mathrm{Fe}(\mathrm{OH})_{3}$ などが生成しているこ とを示唆している。したがって, 水酸化物や炭酸塩の生成

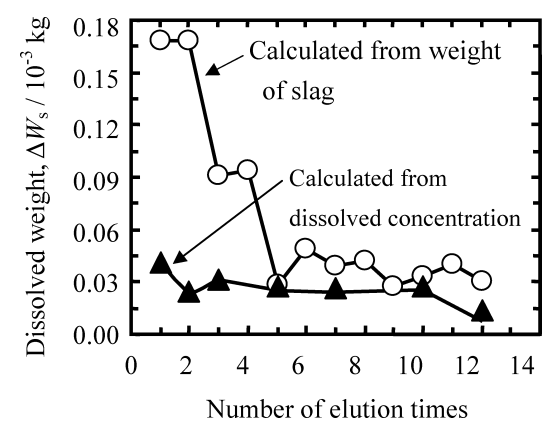

Fig. 14. Relation between dissolved weight a elution test and number of elution times.
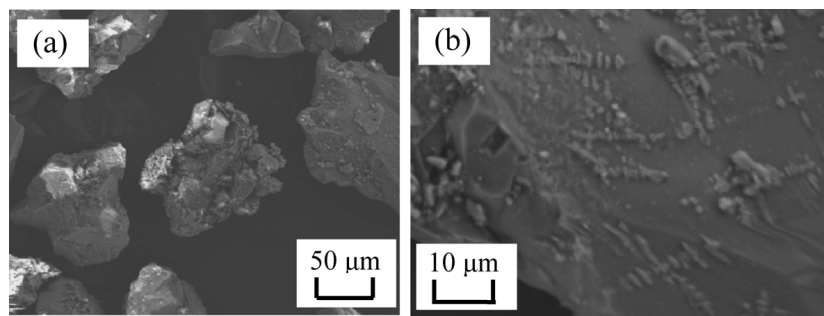

Fig. 15. Pulverized slag particles, (a), and magnification of surface of it, (b).

量はそれらが生成していたとしても小さいと推定される。

\section{$3 \cdot 2 \cdot 3$ スラグの重量変化}

Fig.13に示したように, スラグの溶出により溶出回数の 増加とともにスラグの重量は減少した。JIS K 0058-1にもと づく本法では, 溶出試験にスラグは $100 \times 10^{-3} \mathrm{~kg}$ 必要であ る。溶出 12 回後のスラグは $99.2 \times 10^{-3} \mathrm{~kg}$ であるので，スラ グ重量はほとんど変化していないといえる。溶出回数ごと の溶出量はスラグの重量変化から算出できる。溶出 1 回ご との溶出重量と溶出回数との関係を Fig.13に示す。溶出重 量は溶出回数の増加とともに減少した。 $\mathrm{Al}, \mathrm{Ca}, \mathrm{Fe}, \mathrm{Mg}$ 打よ び $\mathrm{Si}$ の溶出濃度から算出される 1 回の溶出における溶出重 量も同図に併せて示してある。スラグの重量変化から得ら れた溶出重量は濃度から得られたそれよりも大きく, 両者 の差は溶出回数とともに減少した。この溶出重量の差は容 器, フィルターおよびろ紙上に付着した回収できないスラ 


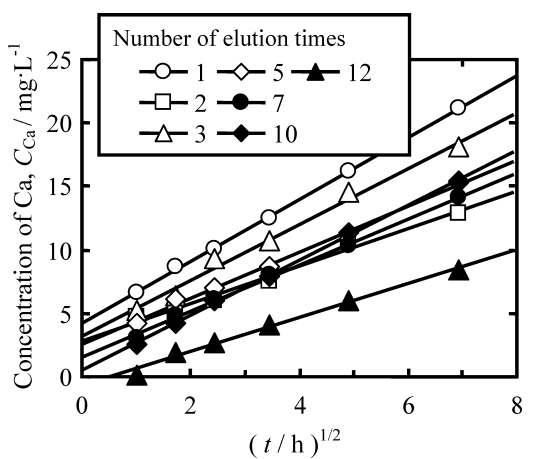

Fig. 16. Adaptability of elution behavior of $\mathrm{Ca}$ to parabolic law given by Eq. ( 3 ).

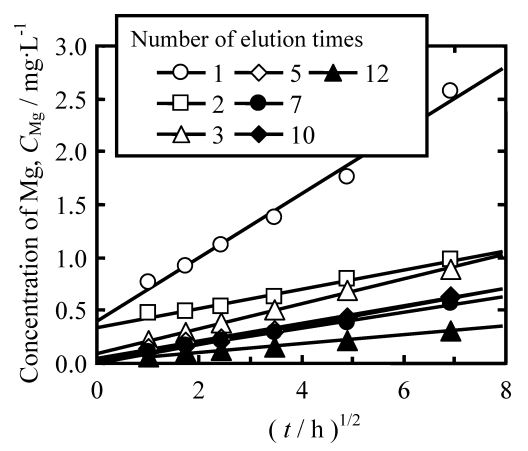

Fig. 17. Adaptability of elution behavior of $\mathrm{Mg}$ to parabolic law given by Eq. ( 3 ).

グ粒子に起因する。それらの粒子を Fig.15(a)に示した。そ れらの粒子は約 $50 \mu \mathrm{m}$ のきさであった。したがって，溶 出回数が少ない場合はそれらの粒子の生成量が大きく, 溶 出回数の增加とともにそれらの生成は小さくなるといえる。 Fig.15(b)にそのスラグ粒子の表面を示す。前述したように， デンドライト周囲のスラグの溶解により, デンドライトが 浮き彫りになっている。この粒子表面全体の化学組成を Table 1に示した。 $\mathrm{Al}_{2} \mathrm{O}_{3}$ と $\mathrm{SiO}_{2}$ の濃度は初期のスラグ組成 より大きいが, $\mathrm{FeO}$ と $\mathrm{CaO}$ は初期の組成よりも小さかった。 $3 \cdot 2 \cdot 4$ 溶出速度

スラグ中の $\mathrm{Ca}, \mathrm{Mg}$ と $\mathrm{Si}$ の溶解挙動は放物線則と直線則

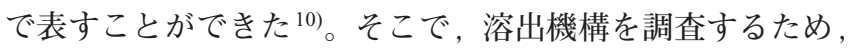
$\mathrm{Ca}, \mathrm{Mg}$ と $\mathrm{Si}$ の溶出濃度の経時変化をそれら2つの法則に適 用してみた。ここで，放物線則と直線則は

Parabolic law: $C_{i}=\alpha t^{1 / 2}+\beta$

Liner law: $C_{i}=\alpha^{\prime} \log t+\beta^{\prime}$

で表される。ここで， $C_{i}$ は時間 $t$ における成分 $i$ の濃度 $\left[\mathrm{mg} \cdot \mathrm{L}^{-1}\right], \alpha$ は定数 $\left[\mathrm{mg} \cdot \mathrm{L}^{-1} \cdot \mathrm{s}^{-1 / 2}\right], \beta, \alpha^{\prime}$ と $\beta^{\prime}$ は定数 $\left[\mathrm{mg} \cdot \mathrm{L}^{-1}\right]$ である。通常, 放物線則は変数 $\beta$ をもたないが, 溶出初期の $\mathrm{pH}$ 上昇に伴う急激な濃度上昇を考慮した。金 属の高温酸化に打ける直線則はその速度が化学反応で律速

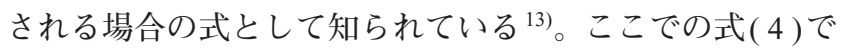
与えられる直線則は, スラグの拡散層が直線的に増加する として導出した ${ }^{10)}$ 。

Fig. 16 と Fig. 17 に $\mathrm{Ca}$ と $\mathrm{Mg}$ の溶出濃度を放物線則に適用

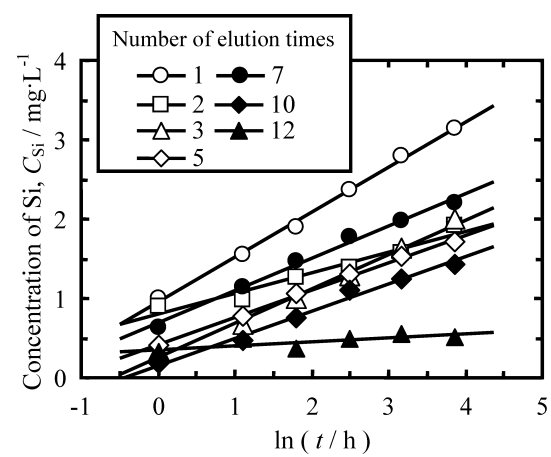

Fig. 18. Adaptability of elution behavior of Si to linear law given by Eq. ( 4 ).

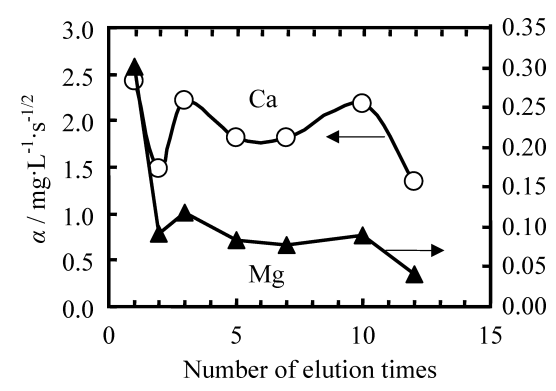

Fig. 19. Relation between parameter of parabolic law given by Eq. ( 3 ), $\alpha$, and number of elution times.

した結果をそれぞれ示す。良い直線関係が得られており， それらの溶出挙動は放物線則で表わされることを示してい る。Fig.18に Siの溶出濃度を直線則にあてはめた結果を示 す。直線関係が得られており, $\mathrm{Si}$ の溶出挙動は直線則で表 されること示している。したがって, $\mathrm{Ca}, \mathrm{Mg}$ と $\mathrm{Si}$ のス グからの溶出速度は拡散によって律速されている。スラグ の溶出はスラグのち密な部分と多孔質な部分の両方で起 こっている。Fig.11と Table 1に示したように, 溶出 12 回 後のスラグ表面での $\mathrm{Al}_{2} \mathrm{O}_{3}$ と $\mathrm{FeO}$ 組成は実験前のそれらよ りも大きい。スラグの溶出はこれらの成分で構成された表 面層と気孔を通しての拡散によって律速されていると考元 られる。

Fig.16 Fig.18に示した直線の切片と傾きから変数 $\alpha, \beta$, $\alpha^{\prime}$ および $\beta^{\prime}$ が得られる。放物線則の変数 $\alpha$ は溶出の速度 に関係している。Fig.19に放物線則の变数 $\alpha$ と溶出回数と の関係を示す。 $\mathrm{Ca}$ の変数 $\alpha$ と溶出回数との関係は振動曲 線で表される。全体的な傾向として, 変数 $\alpha$ は溶出回数に 影響されていないように思える。 $\mathrm{Mg}$ の変数 $\alpha$ は溶出 2 回 目で急激に低下し, その後溶出回数とともに緩やかに減少 した。Fig. 20 に放物線則の変数 $\beta$ と溶出回数との関係を示 す。Caについての変数 $\beta$ は溶出回数の増加とともに直線 的に減少した。 $\mathrm{Mg}$ につての変数 $\beta$ は溶出 3 回目までに 急激に減少した後, 緩やかに減少した。

ここで, 溶出 12 回目の $\mathrm{Ca}$ の変数 $\beta$ は負であったが, こ れは溶出初期に打ける溶解の遅れに起因する。表面層と気 孔を通しての非定常拡散がこの $\mathrm{Ca}$ の変数 $\beta$ に影響してい 


\section{ると考えられる。}

前述したように, $\mathrm{Ca}$ の溶出濃度は溶出回数の増加とと もに減少する傾向にある。このことは, 変数 $\beta$ と溶出回数 との関係に依存しているようである。 $\mathrm{Mg}$ の溶出濃度が溶 出回数の増加とともに減少するのは, 変数 $\alpha$ と $\beta$ の両方が 溶出回数の増加とともに減少することによる。

Fig. 21 に直線則の変数と溶出回数との関係を示す。両変 数と溶出回数との関係は, それぞれ, 振動しながら小さく なる曲線で表される。溶出速度に関係する変数 $\alpha^{\prime}$ と溶出

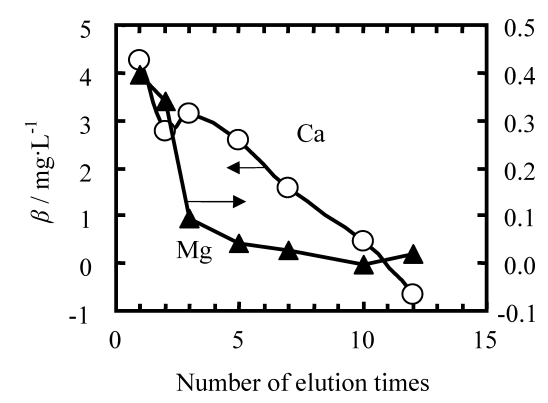

Fig. 20. Relation between parameter of parabolic law given by Eq. ( 3 ), $\beta$, and number of elution times.

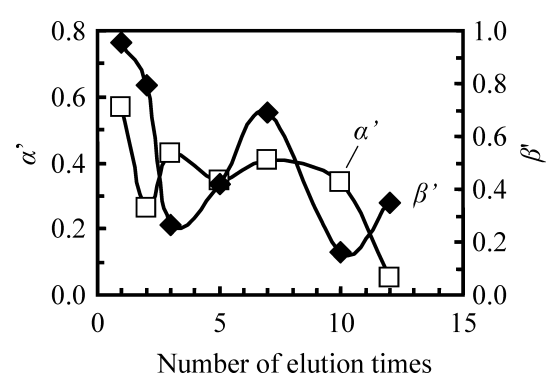

Fig. 21. Relation between parameters of linear law given by Eq. ( 4 ), $\alpha^{\prime}$ and $\beta^{\prime}$, for elution of Si and number of elution times.

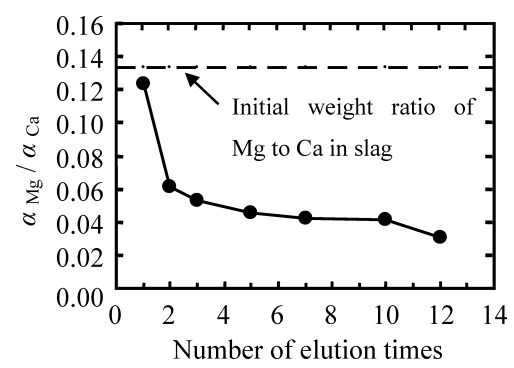

Fig. 22. Relation between ratio of parameter, $\alpha$, for $\mathrm{Mg}$ to that for $\mathrm{Ca}$ and number of elution times.

Table 2. Eluted concentration of environmentally regulated substances and the other minor elemnt, and environmental quality standars. $\left[\mathrm{mg} \cdot \mathrm{L}^{-1}\right]$

\begin{tabular}{|c|c|c|c|c|c|c|c|c|c|}
\hline \multirow{2}{*}{\multicolumn{2}{|c|}{$\begin{array}{c}\text { Number of } \\
\text { elution times }\end{array}$}} & \multirow{2}{*}{1} & \multirow{2}{*}{2} & \multirow{2}{*}{4} & \multirow{2}{*}{9} & \multirow{3}{*}{$\mathrm{RDL}^{* 1}$} & \multicolumn{3}{|c|}{ Environmental quality standards } \\
\hline & & & & & & & \multirow{2}{*}{$\begin{array}{c}\text { Soil } \\
\text { pollution }^{* 2}\end{array}$} & \multirow{2}{*}{$\begin{array}{l}\text { Marine } \\
\text { pollution }^{* 3}\end{array}$} & \multirow{2}{*}{ Water pollutant ${ }^{* 4}$} \\
\hline & lag size, $d / \mathrm{mm}$ & $1 \sim 2$ & $1 \sim 2$ & $1 \sim 2$ & $1 \sim 2$ & & & & \\
\hline \multirow{32}{*}{ 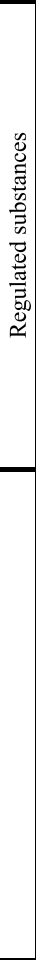 } & Total As & ND & ND & ND & ND & 0.001 & 0.01 & 0.1 & 0.01 \\
\hline & Total B & 0.28 & 0.04 & 0.017 & $\mathrm{ND}$ & 0.01 & 1 & & $1^{* 9}$ \\
\hline & \begin{tabular}{|l} 
Total Be \\
\end{tabular} & ND & ND & ND & $\mathrm{ND}$ & 0.0005 & & 2.5 & \\
\hline & Total Cd & ND & ND & ND & ND & 0.0001 & 0.01 & 0.1 & 0.01 \\
\hline & Total $\mathrm{Cr}$ & ND & ND & ND & ND & 0.005 & & 2 & \\
\hline & Chromium (VI) & $\mathrm{ND}$ & - & - & - & 0.005 & 0.05 & 0.5 & 0.05 \\
\hline & Total $\mathrm{Cu}$ & ND & 0.004 & 0.006 & 0.003 & 0.001 & & 3 & \\
\hline & Total Pb & ND & ND & ND & ND & 0.0005 & 0.01 & 0.1 & 0.01 \\
\hline & $\mathrm{Hg}$ & ND & $\mathrm{ND}$ & ND & $\mathrm{ND}$ & 0.0001 & 0.0005 & 0.005 & 0.0005 \\
\hline & Total Ni & ND & ND & ND & ND & 0.001 & & 1.2 & \\
\hline & Total Se & 0.003 & ND & $\mathrm{ND}$ & ND & 0.002 & 0.01 & 0.1 & 0.01 \\
\hline & Total V & 0.01 & 0.002 & 0.003 & 0.002 & 0.001 & & 1.5 & \\
\hline & Total Zn & 0.014 & 0.013 & 0.006 & 0.007 & 0.005 & & 2 & $\begin{array}{l}0.03^{* 6}, 0.02^{* 7}, \\
0.01^{* 8}\end{array}$ \\
\hline & $\mathrm{F}^{-}$ & 0.5 & 0.5 & 0.1 & ND & 0.1 & 0.8 & 15 & $0.8^{* 9}$ \\
\hline & Total CN & $\mathrm{ND}$ & - & - & - & 0.005 & not detectable & 1 & not detectable \\
\hline & Total Sb & $\mathrm{ND}$ & $\mathrm{ND}$ & ND & ND & 0.0005 & & & \\
\hline & Total $\mathrm{Ba}$ & 0.094 & 0.15 & 0.035 & 0.026 & 0.005 & & & \\
\hline & Total Bi & ND & ND & ND & ND & 0.001 & & & \\
\hline & Total Co & ND & ND & ND & ND & 0.005 & & & \\
\hline & Total Li & ND & ND & ND & ND & 0.05 & & & \\
\hline & Total Mn & ND & 0.006 & 0.004 & 0.029 & 0.002 & & & \\
\hline & Total Mo & 0.007 & 0.001 & ND & ND & 0.001 & & & \\
\hline & Total P & ND & ND & ND & ND & 0.1 & & & $0.005-0.1$ \\
\hline & Total K & 4.8 & 120 & 2.8 & 1.2 & 0.2 & & & \\
\hline & Total Ag & ND & ND & ND & ND & 0.0001 & & & \\
\hline & Total Na & 3.6 & 1.9 & 0.73 & 0.52 & 0.1 & & & \\
\hline & Total Sr & 0.074 & 0.089 & 0.036 & 0.023 & 0.001 & & & \\
\hline & Total S & 1.4 & 0.6 & ND & ND & 0.5 & & & \\
\hline & \begin{tabular}{|l|} 
Total Tl \\
\end{tabular} & ND & ND & ND & ND & $5 \mathrm{E}-05$ & & & \\
\hline & Total Sn & ND & ND & $\mathrm{ND}$ & ND & 0.001 & & & \\
\hline & Total Ti & ND & ND & ND & ND & 0.005 & & & \\
\hline & Total W & 0.056 & 0.016 & 0.009 & 0.005 & 0.001 & & & \\
\hline
\end{tabular}

*1RDL: Reportable detection limit

$* 2$ : Environmental quality standards for soil pollution

*3: Law relating to the prevention of marine pollution and maritime disaster

*4: Environmental quality standards for water pollutants (Environmental quality standards for human health)

$* 5 \mathrm{ND}$ : Not detected

*6: Habitable river or lake for an aquatic (Environmental quality standards for conservation of the living environment)

*7: Habitable coastal water for an aquatic (Environmental quality standards for conservation of the living environment)

*8: Habitable coastal water that needs conservation in particular for nidus and nursery ground (Environmental quality

standards for conservation of the living environment)

*9: Standard values are not aplicable for marine areas 
回数との関係は不明瞭であるが, 溶出濃度の大きさに関与 する変数 $\beta^{\prime}$ は溶出回数の増加とともに減少する。した がって, $\mathrm{Si}$ の溶出濃度は溶出回数の増加とともに減少する ように思われる。

変数 $\alpha, \alpha^{\prime}, \beta^{\prime}$ と溶出回数との関係は振動曲線で表わされ ている。前述したように，スラグは溶出中に粉化する。こ の関係はスラグ表面積の影響や粉化により生成した新生表 面の組成に影響されていることも考えられる。

Fig.22に $\mathrm{Mg}$ の変数 $\alpha$ と $\mathrm{Ca}$ のそれとの比と溶出回数の関 係を示す。放物線則の变数 $\alpha$ は溶出速度に関係しているの で, この変数の比は $\mathrm{Mg}$ と $\mathrm{Ca}$ の溶出速度の比に相等しい。 溶出 1 回目におけるこの変数の比はスラグに含まれる $\mathrm{Mg}$ と $\mathrm{Ca}$ の重量比にほほ等しく, 溶出回数の増加とともに比 は小さくなる。12回溶出後の $\mathrm{Mg}$ と $\mathrm{Ca}$ の重量比は Table 1 にした表面組成から算出でき, その值は 0.26 となる。变数 の比はこのスラグ重量の比よりも小さい。したがって, ス ラグの溶出はその表面組成に影響されない。 $\mathrm{Ca}, \mathrm{Mg}$ と $\mathrm{Si}$ の溶解はスラグ表面層を通しての拡散律速と推定されてい る。Fig. 1に示したように, 使用したスラグは 4 つの酸化 物で構成されている。この結果はスラグの溶出が合同に進 行していないことを示している。

\section{$3 \cdot 3$ 微量元素の溶出}

Table 2 に微量元素の溶出濃度を示す。土壇污染, 海洋污 染および水質污濁防止法に対する環境基準も参考として併 せて同表に示した。JIS K 0058-1での溶出試験では, 初期 $\mathrm{pH}=6.0$ の水にスラグを 6 時間溶出させる。本条件で得ら れた溶出濃度は土䁃污染に関する環境基準を参照しなけれ ばならない。環境規制物質の中で $\mathrm{B}, \mathrm{Cu}, \mathrm{V}, \mathrm{Zn}$ と Fが検出さ れたが，これらの濃度は土䁃打よび海洋污染防止法による 環境基準以下であった。全般的に見て, これらの濃度は溶 出回数の増加とともに減少した。 $\mathrm{Zn}$ の溶出濃度は水質污 濁防止法の環境基準を超えている。前述したように，水質 污濁防止法には溶出試験などはなく，水質を監視する法律 である。したがって, 本条件で得られた Zn濃度が水質污 濁防止法の環境基準を超えていても問題とはならない。し かし，本スラグを水域で実使用する場合には注意を払わな ければならない。

Table 2の下段に示したように，環境規制元素以外にBa， $\mathrm{Mn}, \mathrm{Mo}, \mathrm{K}, \mathrm{Na}, \mathrm{Sr}$ とWが検出された。全般に見て $\mathrm{Mn}$ 除くそれらの濃度は, 環境規制物質の濃度と溶出回数との 関係と同様に, 溶出回数の増加とともに減少した。

環境規制物質とそのほかの微量元素がスラグのどこにど れくらい存在しているかは明らかにできない。単純に, こ れらの元素がスラグに均質に存在していると仮定すると， それらの溶出濃度はスラグの溶出重量が増加すると増加す
るだろう。Fig.14に示したように, スラグの溶出重量は溶 出回数の増加とともに減少しているので, それら微量成分 の溶出濃度も溶出回数の増加とともに減少したと考えられ る。

\section{4. 結論}

普通鋼溶製時に電気炉から排出された酸化スラグの連続 回分溶出試験を JIS K 0058-1にもとづいて行った。得られ た結果を要約して以下に記す。

(1) 環境規制物質の溶出濃度は土㽮污染に関する環境 基準以下であった。したがって, 電気炉酸化スラグを陸上 で使用できる。全般的に見て, それらの濃度は溶出回数の 増加とともに減少した。

（2）水溶液の $\mathrm{pH}$ は溶出初期において急激に増加した 後, 徐々に減少した。 $\mathrm{pH}$ は溶出回数の増加とともに減少 した。

（3） $\mathrm{Ca}$ と $\mathrm{Mg}$ の溶出挙動は放物線則で, $\mathrm{Si}$ のそれは直 線則でそれぞれ表された。それらの溶出はスラグ表面を通 しての拡散に律速されていると推定される。全般的に見て， 溶出濃度は溶出回数の増加とともに減少した。

(4) スラグ溶出時に約 $50 \mu \mathrm{m}$ の微細スラグ粒が生成し た。その粒子の発生は溶出回数の増加とともに減少した。

本研究は, 科研費 20560692 の助成を受けたものである。 これを記し，謝意を表します。また，研究の一部を援助し， 酸化スラグを提供していただいたトピー工業株式会社に深 甚の謝意を表します。

\section{文献}

1 ) Nippon Slag Association: Tekko Sulagu Toukeinennpyou, (2009), 12.

2 ) J.H.Martin: Paleoceanography, 5 (1990), 1.

3 ) T.Miki, T.Nagasaka and M.Hino: Bull. Iron Steel Inst. Jpn., 8 (2004), 34

4 ) T.Miki, T.Nagasaka and M.Hino: Materia Jpn., 41 (2002), 775.

5 ) T.Miki, T.Futatsuka, K.Shitogiden, T.Nagasaka and M.Hino: ISIJ Int., 44 (2004), 753, 762, 935.

6 ) T.Futatsuka, K.Shitogiden, T.Miki, T.Nagasaka and M.Hino: Tetsuto-Hagané, 89 (2003), 382, 388

7 ) R.Inoue and, H.Suito: Tetsu-to-Hagané, 88 (2002), 340, 347.

8 ) H.Suito and R.Inoue: ISIJ Int., 42 (2002), 785, 921.

9 ) S.Yokoyama, A.Suzuki, M.Kawakami, M.Izaki and M.Umemoto: Proc. of ICS 2008, (2008), 191.

10) S. Yokoyama, A. Suzuki, M. Izaki and M. Umemoto: Tetsu-toHagané, 95 (2009), No. 5, 48.

11) Public Announcement of Ministry of the Environment, (2003), No. 19.

12) Public Announcement of Environment Agency, (1973), No. 14

13) N. H. Uhlic and R. W. Revie (Supervisor: S.Matsuda, Translator: T. Okamoto, I. Matushima): Husyokuhannou to Sonoseigyo (Dai3ban) Sangyoutosyo, Tokyo, (1989), 190. 